\title{
KUALITAS DAN KESUBURAN AIR BUDIDAYA LELE DUMBO (Clarias gariepinus) DENGAN VOLUME PERGANTIAN AIR BERBEDA
}

\section{QUALITY AND FERTILITY OF WATER IN CATFISH CULTURE WITH DIFFERENT PORTION OF WATER REPLACEMENT}

\author{
Bambang Triyatmo*)
}

\begin{abstract}
Study was conducted to evaluate the quality and productivity of water used during two period catfish culture for 5 months. Catfish fries were cultured in fiberglass containers for two and three months without draining. During 5 months, $0,5,10,20$ or 40 percent of total water volume were replaced daily. The quality and productivity of water were observed every months.
\end{abstract}

Results indicated that the decrease of water qualities were more notebly when the water replacement in the culture system was carried out in less portion. However, the less portion of the water replacement made higher water fertility for the growth of phytoplankton.

Key words : Clarias gariepinus, quality and fertility of water, water replacement

\section{Pengantar}

Budidaya lele dumbo yang semakin intensif mempunyai padat penebaran yang semakin tinggi dan membutuhkan pakan bergizi tinggi untuk menjamin kelangsungan hidup dan mempercepat pertumbuhan. Pakan harus mengandung kadar protein tinggi dan diberikan setiap hari sebanyak 3-5\% dari berat ikan yang dipelihara (Djajasewaka, 1985; Redding dan Middlen, 1991).

Selama periode pemeliharaan ikan (4-6 bulan) selalu diperoleh limbah berupa sisa-sisa pakan dan kotoran ikan. Limbah tersebut merupakan limbah organik dan mineral-mineral anorganik yang dapat menyebabkan peningkatan kesuburan air (eutrofikasi), dan dapat mengakibatkan kualitas air menjadi kurang sesuai untuk kehidupan dan pertumbuhan ikan (Boyd, 1989; Chiang dkk., 1989; Enander dan Hasselstrom, 1994). Lele dumbo dikenal mampu hidup dalam air yang kualitasnya rendah, namun budidaya ikan tersebut lebih berhasil apabila kualitas air kolamnya juga baik.
Masyarakat banyak yang memelihara lele dumbo dalam kolam/bak di lahan pekarangan. Pergantian air dalam kolam/bak tersebut bervariasi, sedikit hingga banyak. Air limbah (buangan) dari kolam kemungkinan dapat mengganggu kehidupan ikan atau organisme akuatik lain di perairan umum, tetapi juga dapat menyebabkan peningkatan kesuburan bagi (fito) plankton atau tanaman air.

Berdasarkan pemikiran tersebut perlu diteliti tingkat kualitas dan kesuburan air limbah budidaya lele dumbo dengan jumlah pergantian air yang berbeda-beda. Tujuan penelitian ini untuk mengetahui pengaruh pergantian air yang berbeda dalam budidaya lele dumbo terhadap tingkat kualitas air dalam hubungannya dengan kehidupan lele dumbo dan tingkat kesuburan air dalam hubungannya dengan perkembangan (fito) plankton.

\section{Bahan dan Metode}

Budidaya lele dumbo dilakukan dalam 15 bak permanen, terdiri dari lima perlakuan volume pergantian air dan tiga ulangan. Ukuran bak adalah $60 \times 60 \times 70 \mathrm{~cm}^{3}$ dengan volume air masing-masing bak \pm 180 liter

\footnotetext{
*) Staf Pengajar Jurusan Perikanan Fakultas Pertanian UGM, Jalan Sosio Justisia, Bulaksumur, Yogyakarta
} 
dan tinggi air dalam bak $\pm 60 \mathrm{~cm}$. Benih lele dumbo ditebar ke dalam masingmasing bak sebanyak 60 ekor $/ \mathrm{m}^{2}$ (20 ekor/bak). Perlakuan pergantian air dengan kode P0, P1, P2, P3 dan P4 secara berurutan sebanyak $0,5,10,20$ dan $40 \%$ volume air/bak/hari. Budidaya lele dumbo dilakukan selama dua periode secara berurutan menggunakan air dalam bak yang sama :

1. Periode ke -1 : Benih lele yang ditebar berumur tiga bulan dengan berat ratarata 13,9 g/ekor (278 g/bak), dipelihara selama dua bulan.

2. Periode ke -2 : Benih lele yang ditebar berumur dua bulan dengan berat rata-rata 6,6 g/ekor (133 g/bak), dipelihara selama tiga bulan.

Setiap hari ikan diberi pakan sebanyak 3-5 $\%$ dari berat ikan total.

Pengamatan dilakukan terhadap kualitas dan kesuburan air. Parameter kualitas air yang diamati dan metodenya adalah sebagai berikut: kecerahan dengan secchi disk, kekeruhan (turbiditas) dengan turbidimeter, temperatur dengan termometer; $\mathrm{pH}$ air dengan $\mathrm{pH}$-meter; kadar $\mathrm{O}_{2}$ terlarut, $\mathrm{CO}_{2}$ bebas, alkalinitas dan bahan organik dengan metode titrasi; kadar $\mathrm{NH}_{3}, \mathrm{NH}_{4}{ }^{+}$, dan $\mathrm{PO}_{4}{ }^{3-}$ dengan spektrofotometer (APHA, 1985). Data hasil pengamatan kualitas dan kesuburan yang diperoleh kemudian dianalisis secara deskriptif sesuai dengan persyaratan hidup lele dumbo dan perkembangan plankton.

\section{Hasil dan Pembahasan}

Berdasarkan hasil pengamatan kualitas dan kesuburan air budidaya lele dumbo selama penelitian, diperoleh rata-rata dan kisaran data seperti yang tersebut dalam Tabel 1.

\section{Kecerahan dan kekeruhan air}

Air budidaya lele dumbo pada awal penelitian mempunyai kecerahan sampai dasar bak (sedalam $\pm 60 \mathrm{~cm}$ ) dan kekeruhan < 25 JTU. Pada akhir penelitian (selama lima bulan), air budidaya lele dumbo dengan pergantian air $0,5,10,20$ dan $40 \%$ volume/hari secara berurutan mempunyai kecerahan mencapai 1, 4, 6, 7 dan $13 \mathrm{~cm}$, sedangkan kekeruhan air mencapai sebesar 802, 487, 218, 160 dan 59 JTU. Selama pemeliharaan lele dumbo, kecerahan air semakin menurun dan kekeruhan air semakin meningkat. Hal ini terjadi karena peningkatan limbah organik dan jumlah plankton dalam air bak. Kecerahan dan kekeruhan air bak kelihatannya tidak mempengaruhi kehidupan lele dumbo, karena ikan tersebut menyukai tempat yang relatif gelap (seperti waktu malam hari). Perubahan perilaku berbagai macam jenis ikan baru terjadi pada kekeruhan lebih besar dari 20.000 mg/L (Irwin, 1945 dalam Boyd, 1979).

\section{Suhu dan derajad keasaman $(\mathrm{pH})$ air}

Air budidaya lele dumbo selama penelitian dengan pergantian air $0,5,10,20$ dan 40 $\%$ volume/hari secara berurutan mempunyai suhu berkisar antara 25,731,$0 ; 25,7-31,0 ; 25,3-30,7 ; 25,7-31,0$ dan 25,3-30,3 ${ }^{\circ} \mathrm{C}$, sedangkan $\mathrm{pH}$ air berkisar antara $6,5-7,4 ; 6,5-7,3 ; 6,5-7,2 ; 6,5-7,1$ dan 6,5-7,0. Selama pemeliharaan lele dumbo, suhu dan $\mathrm{pH}$ air budidaya antar masing-masing perlakuan pergantian air tidak menunjukkan perbedaan yang nyata. Secara umum, suhu dan $\mathrm{pH}$ air masingmasing berkisar antara $25,3-31,0^{\circ} \mathrm{C}$ dan 6,5 - 7,4, serta perubahannya secara mendadak tidak terjadi. Perairan yang ideal bagi pemeliharaan ikan adalah perairan yang mempunyai suhu antara 25$30{ }^{\circ} \mathrm{C}$ dan $\mathrm{pH}$ antara 6,5 - 8,5 (NTAC, 1968). Selama pemeliharaan lele dumbo, suhu dan $\mathrm{pH}$ air budidaya pada masingmasing perlakuan pergantian air masih termasuk sesuai untuk mendukung kehidupan ikan. 
Tabel 1. Kualitas dan kesuburan air budidaya lele dumbo dengan volume pergantian air berbeda selama penelitian

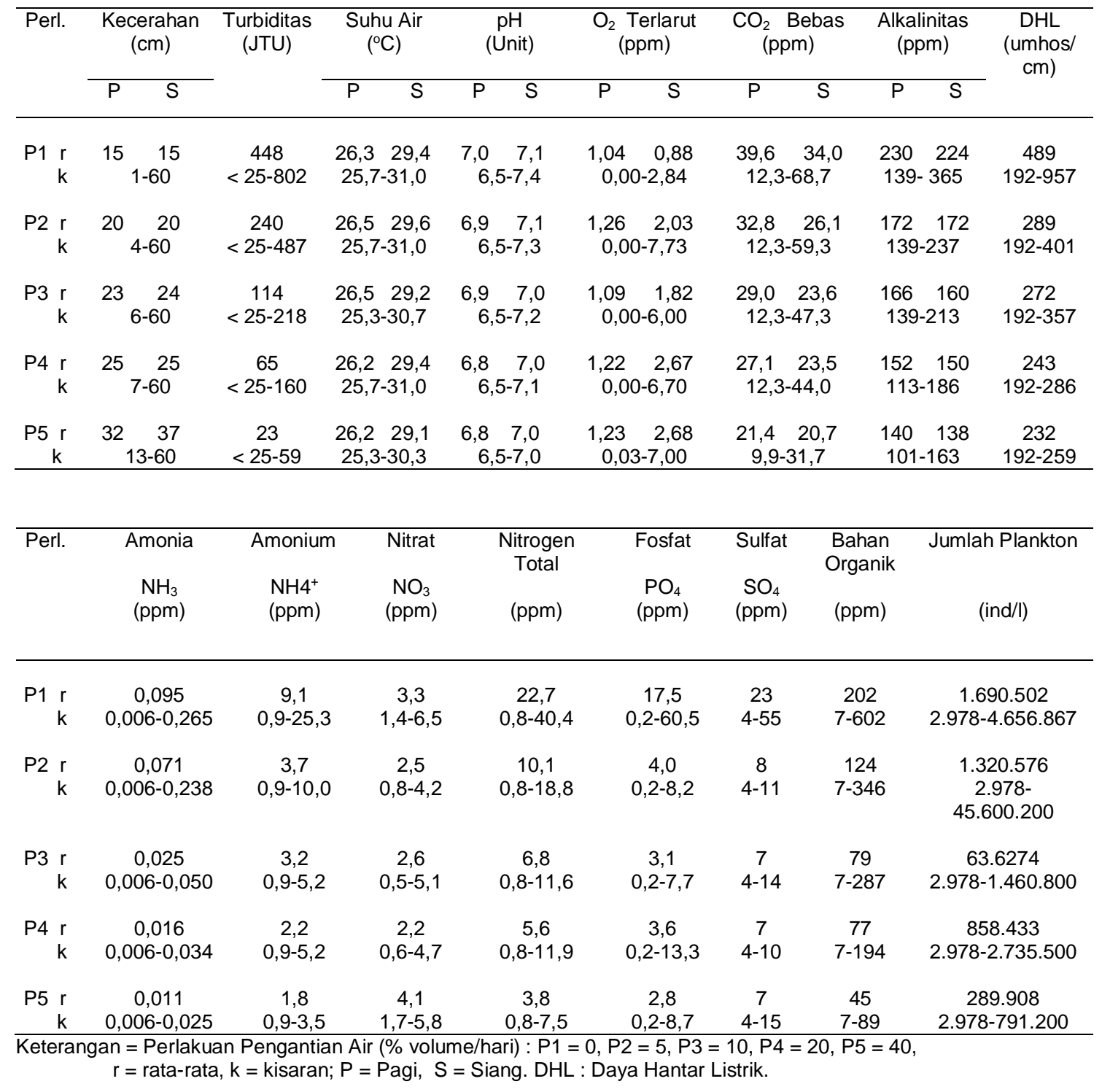




\section{Oksigen $\left(\mathrm{O}_{2}\right)$ terlarut dan karbondioksida $\left(\mathrm{CO}_{2}\right)$}

Air budidaya lele dumbo selama penelitian dengan pergantian air $0,5,10,20$ dan 40 $\%$ volume/hari secara berurutan mempunyai $\mathrm{O}_{2}$ terlarut berkisar antara $0,00-2,84 ; 0,00-7,73 ; 0,00-6,00 ; 0,00-6,70$ dan 0,03-7,00 ppm, sedangkan $\mathrm{CO}_{2}$ berkisar antara 12,3-68,7; 12,3-59,3; 12,347,3; 12,3-44,0 dan 9,9-31,7 ppm. Air budidaya lele dumbo dengan perlakuan yang semakin sedikit pergantian airnya mempunyai kandungan $\mathrm{O}_{2}$ terlarut semakin rendah dan kandungan $\mathrm{CO}_{2}$ semakin tinggi. Selama pemeliharaan lele dumbo (lima bulan), kandungan $\mathrm{O}_{2}$ terlarut air bak pada masing-masing perlakuan semakin menurun, sedangkan kandungan $\mathrm{CO}_{2}$ semakin meningkat. Oksigen terlarut air dalam bak pemeliharaan lele dumbo berkisar antara 0,00-2,84 ppm (rata-rata 0,96 ppm). $\mathrm{CO}_{2}$ air dalam bak pemeliharaan lele dumbo berkisar antara 12,3 - 68,7 ppm (rata-rata 36,8 ppm). Secara umum dalam waktu lama jika kadar $\mathrm{O}_{2}<1$ ppm dapat menyebabkan kematian ikan, sedangkan jika $<5$ ppm ikan masih tetap hidup tetapi pertumbuhannya lambat (Swingle, 1969 dalam Boyd, 1979). Lele dumbo mempunyai organ pernafasan yang mampu mengambil $\mathrm{O}_{2}$ dari udara (Zonneveld dkk., 1991), sehingga dapat hidup di dalam air tanpa atau sedikit $\mathrm{O}_{2}$ terlarut dan kadar $\mathrm{CO}_{2}$ tinggi hingga 71,45 ppm (Areerat, 1987).

\section{Alkalinitas air}

Air budidaya lele dumbo selama penelitian dengan pergantian air 0, 5, 10, 20 dan 40 $\%$ volume/hari secara berurutan mempunyai alkalinitas berkisar antara 139-165, 139-237, 139-213, 113-186 dan 101-163 ppm $\mathrm{CaCO}_{3}$. Air budidaya lele dumbo dengan perlakuan yang semakin sedikit pergantian airnya mempunyai alkalinitas yang semakin tinggi. Selama pemeliharaan lele dumbo (lima bulan), alkalinitas air bak pada masing-masing perlakuan relatif semakin meningkat. Alkalinitas air bak pemeliharaan lele dumbo mempunyai nilai rata-rata sebesar
138-230 ppm. Air bak pemeliharaan pada masing-masing perlakuan mempunyai alkalinitas air yang termasuk sedang hingga tinggi (Swingle, 1968). Produktivitas perairan yang lebih besar bukan akibat langsung dari konsentrasi alkalinitas yang lebih tinggi, tetapi dari tingkat fosfat atau hara-hara esensial lainnya yang tinggi sesuai dengan tingginya alkalinitas. Perairan yang mempunyai alkalinitas rendah secara biologis dianggap kurang produktif (Boyd, 1979).

\section{Daya hantar listrik}

Air budidaya lele dumbo pada awal penelitian mempunyai daya hantar listrik sebesar 192 umhos/cm. Pada akhir penelitian (selama lima bulan), air budidaya lele dumbo dengan pergantian air 0, 5, 10, 20 dan $40 \%$ volume/hari secara berurutan mempunyai daya hantar listrik mencapai 957, 401, 357, 286, 259 dan 249 umhos/cm. Air budidaya lele dumbo dengan perlakuan yang semakin sedikit pergantian airnya mempunyai nilai $\mathrm{DHL}$ yang semakin tinggi. Selama pemeliharaan lele dumbo (lima bulan), nilai DHL air bak pada masingmasing perlakuan relatif semakin meningkat. Dalam perairan lunak (soft water) untuk kehidupan yang baik, ikan dapat menerima $\mathrm{DHL}$ yang berkisar antara 150 - 500 umhos $/ \mathrm{cm}$. Pada nilai DHL di atas 500 umhos/cm ikan mulai dalam keadaan stres, sedangkan diatas 1000 umhos/cm ikan tidak tahan hidup (Sylvester 1958 dalam Kartamihardja dkk., 1987). Nilai DHL air pemeliharaan lele dumbo mempunyai nilai rata-rata sebesar 218-389 umhos $/ \mathrm{cm}$. Air pemeliharaan pada masing-masing perlakuan mempunyai nilai $\mathrm{DHL}$ yang masih sesuai untuk kehidupan lele dumbo.

\section{Nitrogen (amonia, amonium, nitrat, dan nitrogen total)}

Air budidaya lele dumbo selama penelitian dengan pergantian air $0,5,10,20$ dan 40 $\%$ volume/hari secara berurutan mempunyai kadar amonia berkisar antara 
0,006-0,265; $\quad 0,006-0,238 ; \quad 0,006-0,050$; 0,006-0,034 dan 0,006-0,025 ppm, kadar amonium berkisar antara 0,9-25,3; 0,910,$0 ; 0,9-8,1 ; 0,9-5,2$ dan 0,9-3,5 ppm, kadar nitrat berkisar antara $1,4-6,5 ; 0,8-$ 4,2; 0,5-5,1; 0,6-4,7 dan 1,7-5,8 ppm, dan kadar nitrogen total berkisar antara 0,840,$4 ; 0,8-18,8 ; 0,8-11,6 ; 0,8-11,9$ dan $0,8-$ $7,5 \mathrm{ppm}$. Air budidaya lele dumbo dengan perlakuan pergantian air yang semakin sedikit mempunyai kandungan $\mathrm{NH}_{3}, \mathrm{NH}_{4}^{+}$ dan $\mathrm{N}$ total yang semakin tinggi. Selama pemeliharaan lele dumbo (lima bulan), kandungan $\mathrm{NH}_{3}, \mathrm{NH}_{4}{ }^{+}$dan $\mathrm{N}$ total air budidaya lele dumbo pada masingmasing perlakuan relatif semakin meningkat. Kandungan $\mathrm{NO}_{3}{ }^{-}$air budidaya lele dumbo dengan perlakuan yang semakin sedikit pergantian airnya ternyata bervariasi, pada waktu tiga bulan pertama semakin tinggi, sedangkan pada waktu dua bulan terakhir semakin rendah. Kandungan $\mathrm{NH}_{3}, \mathrm{NH}_{4}{ }^{+}, \mathrm{NO}_{3}{ }^{-}$dan $\mathrm{N}$ total air budidaya lele dumbo mempunyai nilai rata-rata masing-masing sebesar 0,0086 $0,0952,0,74-9,12, \quad 2,16-4,05$, dan 1,322,7 ppm. Lele tahan terhadap daya racun $\mathrm{NH}_{3}$. Kadar $\mathrm{NH}_{3}$ air bersifat akut terhadap lele pada konsentrasi 3,8 ppm. Kadar $\mathrm{NH}_{3}$ air maksimal yang masih aman bagi ikan pada umumnya adalah 1,0 ppm (Boyd, 1979). Amonia air budidaya lele dumbo pada masing-masing perlakuan tidak bersifat mengganggu kehidupan ikan. Air budidaya lele dumbo dengan perlakuan yang semakin sedikit pergantian airnya mempunyai tingkat kesuburan air $\left(\mathrm{NH}_{4}{ }^{+}\right.$dan $\left.\mathrm{NO}_{3}{ }^{-}\right)$yang semakin tinggi yang sesuai untuk mendukung pertumbuhan (fito) plankton.

\section{Fosfat dan sulfat}

Air budidaya lele dumbo pada awal penelitian mempunyai kadar $\mathrm{PO}_{4}{ }^{3-}$ dan $\mathrm{SO}_{4}=$ masing-masing sebesar 0,2 dan 4 ppm. Selama penelitian (lima bulan), air budidaya lele dumbo dengan pergantian air $0,5,10,20$ dan $40 \%$ volume/hari secara berurutan mempunyai kadar $\mathrm{PO}_{4}{ }^{3-}$ mencapai 60,$5 ; 8,2 ; 7,7 ; 13,3$ dan 8,7 ppm, sedangkan kadar $\mathrm{SO}_{4}=$ mencapai 55, 11, 14, 10 dan 15 ppm. Air budidaya lele dumbo dengan perlakuan yang semakin sedikit pergantian airnya mempunyai kandungan $\mathrm{PO}_{4}{ }^{3-}$ dan $\mathrm{SO}_{4}=$ yang semakin tinggi. Selama pemeliharaan lele dumbo (lima bulan) kandungan $\mathrm{PO}_{4}{ }^{3-}$ dan $\mathrm{SO}_{4}=$ air budidaya lele dumbo pada masing-masing perlakuan relatif semakin tinggi. Kandungan $\mathrm{PO}_{4}{ }^{3-}$ dan $\mathrm{SO}_{4}=$ dalam air yang semakin tinggi berarti kesuburan airnya juga semakin meningkat untuk pertumbuhan (fito) plankton. Hara $P$ dalam bentuk ortofosfat $\left(\mathrm{PO}_{4}^{3-}\right)$ sifatnya larut dalam air dan dapat dimanfaatkan oleh (fito) plankton. Kandungan fosfat dalam perairan umum biasanya tidak pernah lebih dari 0,1 ppm, kecuali jika ada penambahan dari air buangan atau daerah pertanian (Lund, 1971 cit. Krismono dkk., 1987). Dalam keadaan perairan anerob, sulfat direduksi menjadi sulfida. Sulfida dalam bentuk hidrogen sulfida bersifat racun terhadap ikan pada konsentrasi 1,0 ppm (Boyd, 1979).

\section{Bahan organik total}

Air budidaya lele dumbo pada awal penelitian mempunyai kadar bahan organik total sebesar $7 \mathrm{ppm}$. Selama penelitian (lima bulan), air budidaya lele dumbo dengan pergantian air $0,5,10,20$ dan 40 $\%$ volume/hari secara berurutan mempunyai kadar bahan organik total mencapai 602, 346, 287, 194 dan 89 ppm. Air budidaya lele dumbo dengan perlakuan yang semakin sedikit pergantian airnya mempunyai kandungan bahan organik yang semakin tinggi. Selama pemeliharaan lele dumbo (lima bulan), kandungan bahan organik air budidaya lele dumbo pada masing-masing perlakuan semakin meningkat. Perombakan bahan organik dipengaruhi oleh jenis bahan organik, ketersediaan $\mathrm{O}_{2}$ terlarut, derajat keasaman dan suhu air. Perombakan bahan organik akan meningkat jika $\mathrm{O}_{2}$ terlarut selalu tersedia dalam jumlah yang lebih dari cukup, $\mathrm{pH}$ meningkat hingga 8,5 dan suhu meningkat hingga $35^{\circ} \mathrm{C}$ (Boyd, 1982). Kandungan bahan organik dalam air yang semakin tinggi berarti semakin membutuhkan $\mathrm{O}_{2}$ untuk 
perombakan dan melepaskan $\mathrm{CO}_{2}$, serta menghasilkan hara-hara $\mathrm{NH}_{3}, \mathrm{NH}_{4}^{+}, \mathrm{NO}_{3}^{-}$, $\mathrm{PO}_{4}{ }^{3-}$ dan $\mathrm{SO}_{4}=$ yang semakin banyak. Hasil perombakan tersebut dapat meningkatkan kesuburan air, tetapi juga dapat bersifat racun terhadap ikan (Boyd, 1989; Anonim, 1991).

\section{Plankton}

Air budidaya lele dumbo pada awal penelitian mempunyai jumlah plankton sebanyak 2.978 individu/l. Selama penelitian (lima bulan), air budidaya lele dumbo dengan pergantian air $0,5,10,20$ dan $40 \%$ volume/hari secara berurutan mempunyai jumlah plankton mencapai 4.656.867, 4.560.200, 1.460.800, 2.735.500, 791.200 individu/l, dengan ratarata sebanyak 1.690.502, 1.320.576, 636.274, 858.433 dan 289.908 individu/l. Secara umum air budidaya lele dumbo dengan perlakuan yang semakin sedikit pergantian airnya mempunyai jumlah plankton yang semakin banyak. Selama pemeliharaan lele dumbo (lima bulan) jumlah plankton air budidaya lele dumbo pada masing-masing perlakuan juga semakin meningkat. Jenis plankton yang tumbuh dalam jumlah banyak (dominan) selama penelitian pada masing-masing perlakuan adalah Nitzschia sp., Scenedesmus sp., Synechosystis aqualitis dan Chlorococcum humicola. Selama pemeliharaan lele dumbo (lima bulan) selalu diperoleh sisa-sisa pakan dan kotoran ikan. Bahan organik ini dapat termineralisasi yang dapat menyebabkan peningkatan kesuburan air (eutrofikasi), sehingga jumlah plankton juga semakin banyak (Boyd, 1989; Chiang dkk., 1989; Enander dan Hasselstrom, 1994).

\section{Kesimpulan}

Dari penelitian ini dapat disimpulkan sebagai berikut :

a. Kualitas air semakin menurun pada volume pergantian air budidaya lele dumbo yang semakin sedikit, tetapi masih layak untuk kehidupan lele dumbo.

b. Kesuburan air untuk pertumbuhan dan perkembangan (fito) plankton semakin tinggi pada volume pergantian air budidaya lele dumbo yang semakin sedikit.

\section{Daftar Pustaka}

Anonim. 1991. Shrimp Feed Affects Water Quality. Asian Shrimp News, $3^{\text {rd }}$ Quarter. 4p.

APHA. 1985. Standard Methods for The Examination of Water and Wastewater. American Public Health Association. Washington. $16^{\text {th }}$ edition.

Areerat, S. 1987. Clarias Culture in Thailand. Aquaculture. 63: 355-360.

Boyd, C.E.,. 1979. Water Quality in Warm Water Fish Ponds. Carffmaster. Inc, Opelika, Alabama.

1982. Water Quality Management for Pond Fish Culture. Elsevier Sci. Publ. Co, Amsterdam. 319 p.

1989. Water Quality Management and Aeration in Shrimp Farming. Fisheries and Allied Aquacultures Departemental Series No. 2. Alabama Agricultural Experiment Station, Auburn University, Alabama. $70 \mathrm{p}$.

Chiang, P.D.-M, C-M Kuo and C-F Liu. 1989. Pond Preparation for Shrimp Growth in Proceedings of the Southeast Asia Shrimp Farm Management Workshop. D.M. Akiyama (editor). American Soybean association. Singapore. $48-55 \mathrm{p}$.

Djajasewaka, H. 1985. Pakan Ikan. C.V. Yasaguna, Jakarta. $47 \mathrm{p}$.

Enander, M. dan Mans Alasselstrom. 1994. An Experimental Wastewater 
treatment system for a shrimp farm. Infofish international. 4: 56-61.

Kartamihardja, E.S., A.S. Nastiti, Krismono, K. Purnomo dan A. Hardjamulia. $1987 . \quad$ Penelitian Limnobiologis Waduk Saguling pada Tahap Pra-inundasi. Bull. Penel. Perik. Darat. 6(3) 32-62.

Krismono, E.S., D.H.W. Tjahyo, A. Hardjamulia, S. Nuromah, C. Umar. 1987. Penelitian Limno Biologis Waduk Saguling pada Tahap Post- inundasi. Bull. Penel. Perik. Darat. 6(3): 1-3.

NTAC. 1968. Water Quality Criteria. FWPCA, Washington DC.234 p.

Redding, T.A. dan Midlen, A.B. 1991. Fish Production in Irigation Canals. $A$ Review. FAO Fisheries Technical Paper. No. 317. Rome, FAO. 111 p.

Swingle, H.S. 1968. Standardization of Chemical Analysis for Waters Ponds Muds. FAO Fish. Rep. 44(4): 397-406. 